\title{
A Note on the Translations
}

\author{
NICHOLAS BENSON AND ELENA CODA
}

This is the first time that a wide array of Slataper's work has been translated into English. Apart from Il mio Carso, translated here in its entirety, the volume also includes excerpts from his Lettere triestine, his political writings and critical essays. Overall, the aim of this volume is to present to an English-speaking audience the work of an author whose literary and political reflections open a window onto a unique geopolitical area and cultural milieu that is still relevant today as we reflect on issues of national and cultural identities and international economic influences. ${ }^{1}$

The translation itself is the result of a joint effort over several years of intensive translation, editing, and discussion on how to render a particular word, phrase, or in some instances whole paragraphs whose meaning was difficult to grasp. Working with shared documents and utilizing Skype, we were able to collaborate both long distance and in the moment. We soon realized that for us, translating Slataper involved using two different approaches, which better suited his novelistic and essayistic styles. We approached the challenge of rendering into English the often-winding sentences more typical of early-twentieth-century Italian prose, whether of the critico or the romanziere, in somewhat divergent ways according to genre. As we discovered, we were more likely to break down Slataper the critic's often convoluted style in order to convey

1 Recently the city of Trieste has been in the news both in Italy and abroad because the Italian government allowed China to invest money in the construction of a new pier in its port to facilitate the distribution of Chinese goods in Europe. As the New York Times reported on 18 March 2019, the new pier will allow "favorable custom conditions [for Chinese goods], a faster trade route to the heart of the Continent and direct access to railroads for moving [Chinese] goods into the European Union" (https://www .nytimes.com/2019/03/18/world/europe/italy-trieste-china-belt-road.html). 
his point clearly, while seeking to preserve his account of his thinking process. Slataper romanziere more deliberately deploys a broad syntactical canvas, with dramatic shifts of language and style, in order to mirror an array of thoughts and emotions. As this complexity is an intrinsic part of the novel's texture, we tried to be as true to the original as possible, altering syntax only where necessary in the transformation from Italian to English. Slataper's aesthetic disposition towards a fragmented modernist style embraced by the Vociani, who distrusted traditional narrative modes of expression, is combined with the author's proclivity, especially in the first part of the text, to adopt a sensual and aestheticized prose reminiscent of D'Annunzio's work. Thus, along the way, the novel challenges the translator to mimic its sudden starts and stops, its propulsive energy and power to evoke sensation.

Another type of challenge is posed by the instances of Triestine dialect and diction, which occur when the young Scipio reports the words of his companions, and are accompanied in Italian editions by notes providing the standard Italian equivalents. We sought to maintain the playful spirit of these interjections, without introducing distracting cultural incongruencies. It is of course impossible to find an adequate equivalent for Triestine in English, or any other language; what wins out is the imperative to maintain a colloquial and idiomatic form of speech that renders the nuances of the original. Some of the flavour of the original is undoubtedly lost, but without an intruding dislocation. A further difficulty posed by Slataper's Karst is the author's propensity to switch suddenly from past tense to present in a way that often disorients the reader. We decided to keep the original inconsistency of Slataper's use of verb tenses, which underscores the complication or deliberate undermining of traditional linear temporal narrative. Laying bare the texture of time and memory in this way seems entirely appropriate to a text that resists genre and that Slataper and others struggled to categorize, alternately calling it a lyrical autobiography, memoir, or novel. Slataper himself first entitled his work Carsina; then Vita e sentimenti di Giusto da Trieste, next, Il mio Carso e la mia città; and finally, at the publisher's request, more simply Il mio Carso. We decided to go back to My Karst and My City, the title we prefer for our own edition, because it brings to the fore the tension between the nostalgic, bucolic, regenerative world of the Karstic plateau that surrounds the city, and the fragmented, cacophonous experience of the modern metropolis that Slataper chose to embrace at the end of his narrative and existential journey.

In translating the critical writings, we kept foremost our duty to convey Slataper's ideas as clearly as we could, preserving the complexity of the sentences when Slataper was intent on conveying a laborious thought process. Although adhering to the intellectual rhythm of the original 
may give the translation at times an antiquated flavour, we found this preferable to a modernization of Slataper's prose.

In the end we consider that (after Valéry) a translation is never finished, only abandoned when one has to settle on a version to publish. Although every effort has been made to sift through the volume you are now holding in your hand to ensure the absence of egregious mistakes, we recognize that improvements come with each successive translation. Slataper's writings were all published in a very short span of time, from 1909 to 1915 . After all this time, just as we celebrated the one-hundredyear anniversary of the end of World War I, we propose his writings in the first scholarly edition in English. We hope that this edition will allow readers to engage with the work of this seminal Triestine author who offered us a window on local, national, and international conflicts as they were developing in Europe at the beginning of the twentieth century. Slataper's engagement with Triestine reality, his commitment to observe, critique, explain, and clarify to himself first of all, and then to others, the political tendencies and the cultural tensions he witnessed in his multi-ethnic city, was always guided by a desire to inform his public about the geopolitical complexity of his place and time without falling into any facile rhetoric popular at his time. He embodied the figure of the engaged intellectual who questioned traditional interventionist and nationalist positions, but at the same time was willing to change or reformulate his opinions as circumstances changed, and, most of all, took full responsibility for his writings and for his actions. As such, Slataper remains a remarkable figure worth reading and studying.

\section{Citations and Texts}

Elena Coda's notes to the translations facilitate the identification of peoples, places, and contexts that might not be familiar to the contemporary reader. In order to distinguish the editor's notes from the notes provided by the author, Coda's notes appear within brackets. Unless otherwise noted, the biographical and historical information was obtained from the Enciclopedia Treccani and the Encyclopedia Britannica.

The translations are based upon the following editions:

Slataper, Scipio. Alle tre amiche. Edited by Giani Stuparich, Mondadori, 1958.

- Ibsen. Edited by Arturo Farinelli, Fratelli Bocca, 1916.

- Il mio Carso. Photomechanical reproduction of the 1st ed. (1912), della Libreria della Voce (Florence), under the aegis of the city of Trieste, 1989. 
- Scritti letterari e critici. Edited by Giani Stuparich, Mondadori, 1956. ("Ai giovani intelligenti d'Italia"; "Il futurismo"; "Perplessità crepuscolare")

- Scritti politici. Edited by Giani Stuparich, Alberto Stock, 1925. ("Trieste non ha tradizioni di cultura"; "La vita dello spirito"; "Oggi"; "L'avvenire nazionale e politico di Trieste"; "I diritti nazionali si affermano con la guerra") 


\section{MY KARST \\ AND MY CITY AND OTHER ESSAYS}


This page intentionally left blank 